\title{
Contrasting transcriptome response to thermal stress in two key zooplankton species, Calanus finmarchicus and C. glacialis
}

\author{
Irina Smolina ${ }^{1, *}$, Spyros Kollias ${ }^{1}$, Eva F. Møller ${ }^{2}$, Penelope Lindeque $^{3}$, \\ Arvind Y. M. Sundaram ${ }^{4}$, Jorge M. O. Fernandes ${ }^{1}$, Galice Hoarau ${ }^{1}$ \\ ${ }^{1}$ Faculty of Biosciences and Aquaculture, University of Nordland, 8049 Bodø, Norway \\ ${ }^{2}$ Department of Bioscience, Aarhus University, Frederiksborgvej 399, 4000 Roskilde, Denmark \\ ${ }^{3}$ Plymouth Marine Laboratory, Prospect Place, West Hoe, Plymouth PL1 3DH, UK \\ ${ }^{4}$ Norwegian Sequencing Centre, Department of Medical Genetics, Oslo University Hospital, Kirkeveien 166, 0407 Oslo, Norway
}

\begin{abstract}
Climate change has already led to the range expansion of warm-water plankton assemblages in the northeast Atlantic and the corresponding range contraction of colder-water species. The temperate copepod Calanus finmarchicus is predicted to shift farther northward into polar waters traditionally dominated by the arctic copepod C. glacialis. To identify temperaturemediated changes in gene expression that may be critical for the thermal acclimation and resilience of the 2 Calanus spp., we conducted a whole transcriptome profiling using RNA-seq on an Ion Torrent platform. Transcriptome responses of C. finmarchicus and C. glacialis from Disko Bay, west Greenland, were investigated under realistic thermal stresses (at $+5,+10$ and $+15^{\circ} \mathrm{C}$ ) for $4 \mathrm{~h}$ and $6 \mathrm{~d}$. C. finmarchicus showed a strong response to temperature and duration of stress, involving up-regulation of genes related to protein folding, transcription, translation and metabolism. In sharp contrast, C. glacialis displayed only low-magnitude changes in gene expression in response to temperature and duration of stress. Differences in the thermal responses of the 2 species, particularly the lack of thermal stress response in C. glacialis, are in line with laboratory and field observations and suggest a vulnerability of $C$. glacialis to climate change.
\end{abstract}

KEY WORDS: RNA-seq - Copepods - Temperature stress response - Heat shock protein · Climate change

\section{INTRODUCTION}

Climate change profoundly impacts both marine and terrestrial ecosystems, ranging from biogeographical and phenological changes to abrupt ecosystem shifts (Thackeray et al. 2008, Beaugrand et al. 2009). Its effects are particularly intense in the Arctic, where temperatures have increased 2 to 4 times faster in the past few decades compared to the global average (Hansen et al. 2006). A striking consequence of climate change is the range expansion of warmwater plankton assemblages in the northeast Atlan-

*Corresponding author: ism@uin.no tic, and the corresponding range contraction of coldwater species (Beaugrand et al. 2002, 2009). The increase in water temperature and different thermal tolerances of copepods appear to be the major drivers of such shifts in zooplankton communities (Beaugrand et al. 2002, 2009, Helaouët \& Beaugrand 2007).

Copepods of the genus Calanus are predominant in the zooplankton biomass of the high-latitude oceanic regions and play a significant role in energy transfer in marine food webs (Falk-Petersen et al. 2009) and in the biological pump of biogenic carbon into the deep sea (Pasternak et al. 2002). The temper-

() The authors 2015. Open Access under Creative Commons by Attribution Licence. Use, distribution and reproduction are unrestricted. Authors and original publication must be credited. 
ate species C. finmarchicus (Gunnerus, 1770), with a temperature range in nature between -1.8 and $15^{\circ} \mathrm{C}$, and the Arctic species C. glacialis Jaschnov, 1955, with a temperature range in nature from -1.8 to $7^{\circ} \mathrm{C}$, can comprise up to 70 to $80 \%$ of the zooplankton biomass in the North Atlantic and Arctic shelf seas, respectively (Conover 1988, Bonnet et al. 2005, Blachowiak-Samolyk et al. 2008, Carstensen et al. 2012). Although there are only very subtle morphological differences between these 2 closely related species, they are adapted to different thermal environments, differ in phenology and energy-rich lipid content, and are suggested to support different Arctic food webs (Conover 1988, Bucklin et al. 1995, Falk-Petersen et al. 2009). A northward shift (ca. $8 \mathrm{~km} \mathrm{decade}{ }^{-1}$ ) of the temperate species C. finmarchicus has been detected, with temperature being one of the main explanatory factors (Beaugrand et al. 2002, Chust et al. 2014). With ongoing climate change, the northward shift of $C$. finmarchicus is predicted to continue into Arctic waters currently dominated by C. glacialis and C. hyperboreus (Helaouët et al. 2011, Wassmann et al. 2011). In addition, warming of the Arctic will likely benefit $C$. finmarchicus more than C. glacialis (Kjellerup et al. 2012), resulting in changes in food-web dynamics and secondary production (Falk-Petersen et al. 2007). Despite an extensive knowledge of the ecology and phenology of these 2 species, the molecular basis of physiological responses (particularly changes in gene expression) to increased water temperature remains largely unexplored. This impairs our understanding of species performance, abundance and distribution in a changing climate, and therefore, reduces our power to predict climate-related shifts in ecosystem structure and function.

Temperature is a crucial factor for an organism's performance, particularly for ectotherms, as their physiological functions are strongly temperaturedependent. Therefore, the biogeographic range and abundance of a species is highly dependent on the thermal tolerance of an organism (e.g. Hofmann \& Todgham 2010). In response to environmental conditions that fluctuate beyond an organism's tolerance limits, an immediate uniform cellular stress response is activated; however, prolonged stress exposure initiates a stressor-specific secondary response (cellular homeostasis response) to re-establish homeostasis under the new environmental conditions (Kültz 2005). One of the components of the cellular stress response is heat shock response, a universal molecular stress response that is particularly well-studied in response to stressful temperatures and mainly in- volves up-regulation of heat shock proteins (HSPs), which act as molecular chaperones (Hofmann \& Todgham 2010). HSPs protect damaged proteins from aggregation, unfold aggregated proteins and refold damaged proteins or target them for efficient degradation (Verghese et al. 2012), thereby stabilizing the functioning of the organism under elevated temperature and increasing its thermal tolerance range (Feder \& Hofmann 1999). Despite the universality of the heat shock response, species adapted to extremely stable and cold environments, such as several Antarctic invertebrates and notothenioid fishes, appear to lack the ability of HSP up-regulation (Bilyk \& Cheng 2014).

The rapid advance in high-throughput sequencing technologies and whole transcriptome profiling (RNA-seq) enables investigation of species that are not yet established genetic models (Wang et al. 2009), but that display thermal tolerance mechanisms that are of high ecological and evolutionary interest (Smith et al. 2013). Studies on transcriptional regulation of gene expression under thermal stress in closely related species have started to emerge only recently, covering a wide range of organisms from amphipods (Bedulina et al. 2013) and mussels (Lockwood et al. 2010) to endosymbiotic dinoflagellates of reef corals (Barshis et al. 2014). However, few studies have targeted Calanus or even copepods.

Here we examined thermal stress responses in the temperate C. finmarchicus and the Arctic C. glacialis simultaneously sampled from the same location and, therefore, sharing thermal histories. Using realistic temperatures and 2 durations of stress, we explored the global transcriptomic patterns of gene expression changes and focused on key differences between the 2 species.

\section{MATERIALS AND METHODS}

\section{Sampling and experimental set-up}

Copepods were collected in Disko Bay, Greenland $\left(69^{\circ} 14^{\prime} \mathrm{N}, 53^{\circ} 23^{\prime} \mathrm{W}\right)$, on 20 April 2012 by vertical hauls with a $200 \mu \mathrm{m}$ net in the upper $100 \mathrm{~m}$, where water temperature ranged between -1 and $1^{\circ} \mathrm{C}$. The sampling site was monitored every week from midMarch. During the whole period, the surface water temperature was below $0^{\circ} \mathrm{C}$, whereas it slowly increased towards the bottom and reached $3^{\circ} \mathrm{C}$ at $200 \mathrm{~m}$ (E. F. Møller \& T. G. Nielsen unpubl. data). The phytoplankton bloom started at the end of April, with a value of $8 \mu \mathrm{g} \mathrm{chl} \mathrm{a} \mathrm{l}^{-1}$ in the surface water. Neither 
Calanus finmarchicus nor C. glacialis were producing eggs 2 wk before sampling, whereas on the day of sampling egg production was 6 and 12 eggs female $\mathrm{e}^{-1} \mathrm{~d}^{-1}$ in $C$. finmarchicus and C. glacialis, respectively (E. F. Møller \& T. G. Nielsen unpubl. data).

Shortly after collection the copepods were transferred to a laboratory in 251 thermo boxes. Owing to difficulties of species identification between live $C$. finmarchicus and C. glacialis, females were selected for experiments and sorted according to the red pigmentation of the antenna and somites (Nielsen et al. 2014). To overcome stress associated with collection, copepods were incubated in $600 \mathrm{ml}$ bottles with an in situ water temperature of $0^{\circ} \mathrm{C}$ for $48 \mathrm{~h}$. During the acclimation and experimental periods, copepods were fed the diatom Thalassiosira weissflogii in accordance with Kjellerup et al. (2012), the density of copepods was 5 individuals per bottle, and the bottles were capped and rotated once a day. The selected copepod density was slightly lower than in previous experiments (e.g. Hjorth \& Nielsen 2011); nevertheless, even at 20 times higher density, the oxygen saturation does not fall lower than $80 \%$ after $21 \mathrm{~h}$ (Hildebrandt et al. 2014). Acclimated copepods were transferred to $600 \mathrm{ml}$ Nunc bottles containing filtered seawater with $\sim 5 \mu \mathrm{g} \mathrm{chl} \mathrm{a} \mathrm{l}^{-1}$ of $T$. weissflogii and incubated at $0,5,10$ and $15^{\circ} \mathrm{C}$ with 8 replicates (bottles) per temperature in each species (Fig. S1 in Supplement 1 at www.int-res.com/articles/suppl/m534 p079_supp.pdf). Half of the replicates of each species were terminated after $4 \mathrm{~h}$ to evaluate a short-term thermal stress (STS) response. Remaining replicates were incubated for $6 \mathrm{~d}$ to evaluate the chronic response to long-term thermal stress (LTS), thus resulting in 20 individuals per treatment (Fig. S1 in Supplement 1). Every second day, copepods were transferred to new bottles with fresh $T$. weissflogii to ensure an excess supply of prey. Mortality was noted and the grazing response to temperature was evaluated by measuring the fecal pellet production during the experiments. At the termination of the experiments the copepods were anaesthetised by bubbling with $\mathrm{CO}_{2}$ and were immediately preserved in RNAlater (Qiagen).

\section{RNA/DNA extraction and genetic species identification}

RNA and DNA were extracted simultaneously from each individual with the E.Z.N.A. DNA/RNA Isolation Kit (Omega Bio-Tek) in accordance with the manufacturer's instructions. To ensure correct spe- cies identification, C. finmarchicus and C. glacialis were genotyped for 3 microsatellite loci (EL696609, EL585922 and EH666870) (Provan et al. 2007) or 6 insertion/deletion (InDel) nuclear markers (Smolina et al. 2014). Individuals were assigned to species (Table S1 in Supplement 2 at www.int-res.com/ articles/suppl/m534p079_supp.xls) in accordance with Smolina et al. (2014).

\section{Transcriptome Ion Torrent PGM sequencing}

C. finmarchicus and C. glacialis, following the $4 \mathrm{~h}$ (STS) and $6 \mathrm{~d}$ (LTS) exposures to 0,5 and $10^{\circ} \mathrm{C}$, were used for transcriptome sequencing. An equal amount of total RNA was pooled from 5 individuals per library to build 12 libraries in total. Pooled RNAs were treated with Baseline-ZERO DNase (Epicentre) and subsequently cleaned using the RNA Clean \& Concentrator kit (Zymo Research). To control for technical variation during library preparation and sequencing, ERCC ExFold RNA Spike-In Mix 1 or 2 (Ambion) was added to each library of $1.6 \mathrm{mg}$ total RNA in a random assessment, following the manufacturer's guidelines. Isolation of mRNA from total RNA was performed using 2 rounds of Mag-Bind mRNA Enrichment (Omega Bio-Tek) with subsequent cleaning using the RNA Clean \& Concentrator kit. Libraries were constructed using $50 \mathrm{ng}$ poly(A) RNA and the Ion Total RNA-Seq Kit for AB Library Builder System (Life Technologies) with individual barcodes from Ion Xpress RNA-Seq Barcode kit (Life Technologies). Emulsion PCR was done with the Ion One Touch 2 System, using the Ion PGM Template OT2 200 Kit (Life Technologies), followed by enrichment and quality control according to the manufacturer's protocol. The 6 libraries of each species were pooled and sequenced with the Ion PGM System using the Ion PGM 200 Sequencing Kit and one Ion 318 chip per species.

\section{RNA-seq analysis}

The transcriptomes from both species were analyzed separately following the same protocol. To check the quality of the libraries, ERCC RNA SpikeIn reads were processed with ERCC_Analysis plugin v.4.0-r72040 implemented in Torrent Suite 4.0.2. ERCC RNA Spike-In reads were then filtered out by mapping to ERCC RNA reference sequences using bowtie2 v.2.2.1 (Langmead \& Salzberg 2012) with '--very-sensitive' parameters. Remaining reads were 
quality trimmed using the fastq_quality_trimmer tool from the FASTX Toolkit v.0.013 with a threshold of a Phred quality score 17, and a length threshold of 35 bp (Ion RNA-Seq 2012). Identical sequences among the reads were collapsed into a single sequence using fastx_collapser from FASTX Toolkit v.0.013 with default parameters. Resulting reads from 6 libraries per species were concatenated for subsequent species-specific de novo assembly and normalization using Trinity v.r2013_08_14 (Haas et al. 2013). Reads were normalized using normalize_ by_kmer_coverage.pl tool with the targeted maximum coverage value of 30 and assembled with default parameters. The assemblies were annotated using local BLASTX (NCBI BLAST 2.2.28+) against the UniProtKB/Swiss-Prot protein database (downloaded on 19 February 2014) with the following parameters: -outfmt 6 std qcovs -evalue $0.00001-\max _{-}$ target_seqs 1.

Cleaned reads were mapped to their respective species assemblies using Subread package v.1.4.3-p1 (Liao et al. 2013) with default parameters. Counts of mapped reads per Trinity transcript were extracted for each library using featureCounts (Liao et al. 2014). Differential gene expression analysis was performed for the 2 species separately using the BioConductor package DESeq2 v.1.4.5 (Love et al. 2014) in R v.3.1.0 (R Development Core Team 2011). Expression profiles of each library were normalized with a size factor calculated from ERCC RNA Spike-In reads belonging to the group $\mathrm{B}$ with functions estimateSizeFactorsForMatrix and sizeFactors. Gene expression data were analyzed with a statistical design that included 2 factors: duration (levels STS and LTS) and temperature (levels 0, 5 and $10^{\circ} \mathrm{C}$ ). Using the function contrast, in total 4 comparisons per species were analyzed: STS versus LTS, 0 vs. $5^{\circ} \mathrm{C}, 0$ vs. $10^{\circ} \mathrm{C}$ and 5 vs. $10^{\circ} \mathrm{C}$. To remove potential sequencing errors, Trinity transcripts with baseMean $<5$ counts were filtered out prior to calling significant differentially expressed transcripts (Barshis et al. 2014). Transcripts were recognized as differently expressed at $\mathrm{q}<0.05$ after a multiple comparison correction with false discovery rate (FDR) (Benjamini \& Hochberg 1995) implemented in the DESeq2 package. The heat map of differentially expressed transcripts was generated using the heatmap. 2 function of the R package gplots (Warnes et al. 2014), where expression counts of each transcript were normalized by dividing counts in each sample by the average expression of that transcript across all samples. Functional enrichment of differentially expressed transcripts was identified using R package topGO (Alexa \& Rahnenfuhrer
2010). The analysis was done for 3 gene ontology (GO) categories (biological process, molecular function and cellular component) using Fisher's exact test and correction for FDR at $\mathrm{q}<0.05$.

\section{Quantitative real-time PCR of selected genes}

Gene selection and design of primers

Validation of the RNA-seq results and sensitivity assessment of our medium throughput approach was performed by quantitative real-time PCR (qPCR) of 11 genes. The genes were chosen either because they were identified from differential expression analysis in the present study (hsp60, hsp70_2, gdh, rp114) or because of their known function in stress response (dnaja1, hsp10, hsp70_3, hsp70_5, nap111, rps11, znf207) (Table S2 in Supplement 2 at www.intres.com/articles/suppl/m534p079_supp.xls). In addition, as reference genes for Calanus during temperature stress have not been reported, 5 genes were tested as putative reference genes for C. finmarchicus and C. glacialis during STS and LTS. Genes $c d c 42$, eif1ax and trx-2 were selected for their stable transcript counts in all libraries, and efa $1 \alpha$ and $16 \mathrm{~S}$ rRNA were selected from the literature on gene expression in C. finmarchicus (Tarrant et al. 2008, Hansen et al. 2013). Reciprocal BLAST searches (MegaBLAST in Geneious 7.1.0 [Biomatters], default settings) were performed between the 2 species to identify homologous genes. Aligned regions were visually inspected and searched for conserved regions to design primers resulting in a product length of between 70 and 150 bp using Primer3 (Koressaar \& Remm 2007) in Geneious 7.1.0 (Table S2 in Supplement 2).

\section{Synthesis of cDNA and qPCR}

qPCR of selected genes was performed for individuals of $C$. finmarchicus ( $\mathrm{n}=6$ to 10 ) and $C$. glacialis (n $=8$ to 10) exposed to $0,5,10$ and $15^{\circ} \mathrm{C}$ for $4 \mathrm{~h}$ and $6 \mathrm{~d}$. RNA was quantified using the Qubit RNA Assay kit (Life Technologies) and a Qubit 2.0 Fluorometer (Life Technologies); integrity of selected RNA from each extraction was checked on a $1 \%$ agarose gel. Total RNA from 6 to 10 samples for each treatment and species (5 of which were also used for RNA-seq), as well as 2 controls (positive control and no-reversetranscriptase control) were individually reversetranscribed to cDNA in $10 \mu$ l reactions using the 
QuantiTect Reverse Transcription Kit (Qiagen) according to the manufacturer's instructions, with a starting amount of $49 \mathrm{ng}$.

The qPCR reactions were carried out in a StepOnePlus Real-Time PCR System (Life Technologies) in a total volume of $5 \mu \mathrm{l}$ containing $2.5 \mu \mathrm{l}$ PerfeCta SYBR Green FastMix (Quanta BioSciences), $2 \mu \mathrm{l}$ cDNA (1:15) and $0.5 \mu \mathrm{l}$ of primer mix with $3 \mu \mathrm{M}$ of forward and reverse primers each. All reactions, including controls and dilution series, were run in duplicate with the following amplification protocol: $95^{\circ} \mathrm{C}$ for $30 \mathrm{~s}$ followed by 40 cycles of $95^{\circ} \mathrm{C}$ for $5 \mathrm{~s}$ and $60^{\circ} \mathrm{C}$ for $20 \mathrm{~s}$ (for all primers). At the end of each qPCR, melting curve analysis of amplified products was performed to verify amplification specificity. The PCR amplification efficiency $(E)$ and the regression coefficient $\left(R^{2}\right)$ were calculated from a dilution series $(1: 3$ dilution/step, from 1:1 to 1:81) of the cDNA pools using the regression slope of the threshold cycle $(\mathrm{Ct})$ versus cDNA quantity plot following Pfaffl et al. (2002). The best reference genes (most stable in expression) were identified separately for $C$. finmarchicus and C. glacialis using geNorm 3.5 and were used to calculate the corresponding normalization factors (Vandesompele et al. 2002).

\section{Statistical analysis}

Data were analysed in R v.3.1.0 (R Development Core Team 2011). Normal distribution and homogenous variance of data were assessed visually by frequency histograms and Q-Q plots. As not all the data satisfied parametric assumptions, nonparametric methods were applied. Effects of the temperature stress duration (STS vs. LTS) and stress temperatures $\left(0,5,10\right.$ and $\left.15^{\circ} \mathrm{C}\right)$ on expression of selected genes were analysed separately. The duration effect was assessed with a Mann-Whitney $U$-test, first for a combination of all stress temperatures, then at each temperature separately with $\mathrm{p}$-value correction for multiple comparisons using the FDR method (Benjamini \& Hochberg 1995). The temperature effect on gene expression and fecal pellet production was assessed with a Kruskal Wallis test separately for STS and LTS. In the case of significant temperature effects, values were compared pairwise between all temperatures with a nonparametric analog of Tukey test in the $\mathrm{R}$ package nparcomp (Konietschke 2012).

Results of RNA-seq and qPCR were compared using the Spearman correlation of $\log _{2}$ fold change (FC) of expression values in all comparisons (STS vs. LTS, 0 vs. $5^{\circ} \mathrm{C}, 0$ vs. $10^{\circ} \mathrm{C}, 5$ vs. $10^{\circ} \mathrm{C}$ ) for 16 genes (except znf207 for C. finmarchicus that had too few reads in RNA-seq to obtain any $\log _{2}$ FC values). Correlation analysis and tests of significance were performed in Hmisc R package (Harrell 2014). The strength of correlation was interpreted in accordance with Mukaka (2012).

\section{RESULTS}

\section{Physiological response}

During the thermal experiments aimed at comparing the transcriptome responses of Calanus finmarchicus and C. glacialis to elevated temperatures, maximum mortality of 20 and $35 \%$ was observed for the 2 species, respectively, at $15^{\circ} \mathrm{C}$ during LTS. Mortality during STS did not exceed $5 \%$ for either species at any temperature. Fecal pellet production, as an indicator for grazing activity, was measured during STS but not during LTS, due to an unnoticed tear in the mesh filter. Fecal pellet production during STS significantly increased with temperature for $C$. finmarchicus until $10^{\circ} \mathrm{C}$ and plateaued at $15^{\circ} \mathrm{C}$ (Fig. S2 in Supplement 1 at www.int-res.com/articles/suppl/ m534p079_supp.pdf), while for C. glacialis it was significantly higher at 5 and $10^{\circ} \mathrm{C}$ compared to $0^{\circ} \mathrm{C}$ and decreased at $15^{\circ} \mathrm{C}$ (Fig. S2 in Supplement 1).

\section{Transcriptome sequencing}

Sequencing of C. finmarchicus and C. glacialis transcriptomes yielded 4837616 and 3307190 reads, respectively, with approximately equal numbers of reads among libraries within each species (Fig. S3 in Supplement 1). Overall, 1.2 to $2.9 \%$ of the reads were mapped to ERCC RNA Spike-In reference sequences, and the good correlation between known concentration and count of mapped reads for each library $\left(R^{2}>0.85\right)$ indicated that all libraries were of good quality. After ERCC RNA Spike-In filtering and quality trimming, cleaned reads represented 87.6 to $93 \%$ of the original raw reads (Fig. S3 in Supplement 1) with mean lengths of 115 and $119 \mathrm{bp}$ for $C$. finmarchicus and C. glacialis, respectively. Trinity assemblies for $C$. finmarchicus and $C$. glacialis resulted in 28954 and 36880 transcripts, respectively (Table 1), with mean transcript lengths of 353 and $427 \mathrm{bp}$. Transcriptome assemblies of the 2 species displayed a similar guanine and cytosine (GC) content (ca. 48\%) and annotation success (ca. 50\%) against UniProtKB/Swiss-Prot protein database 

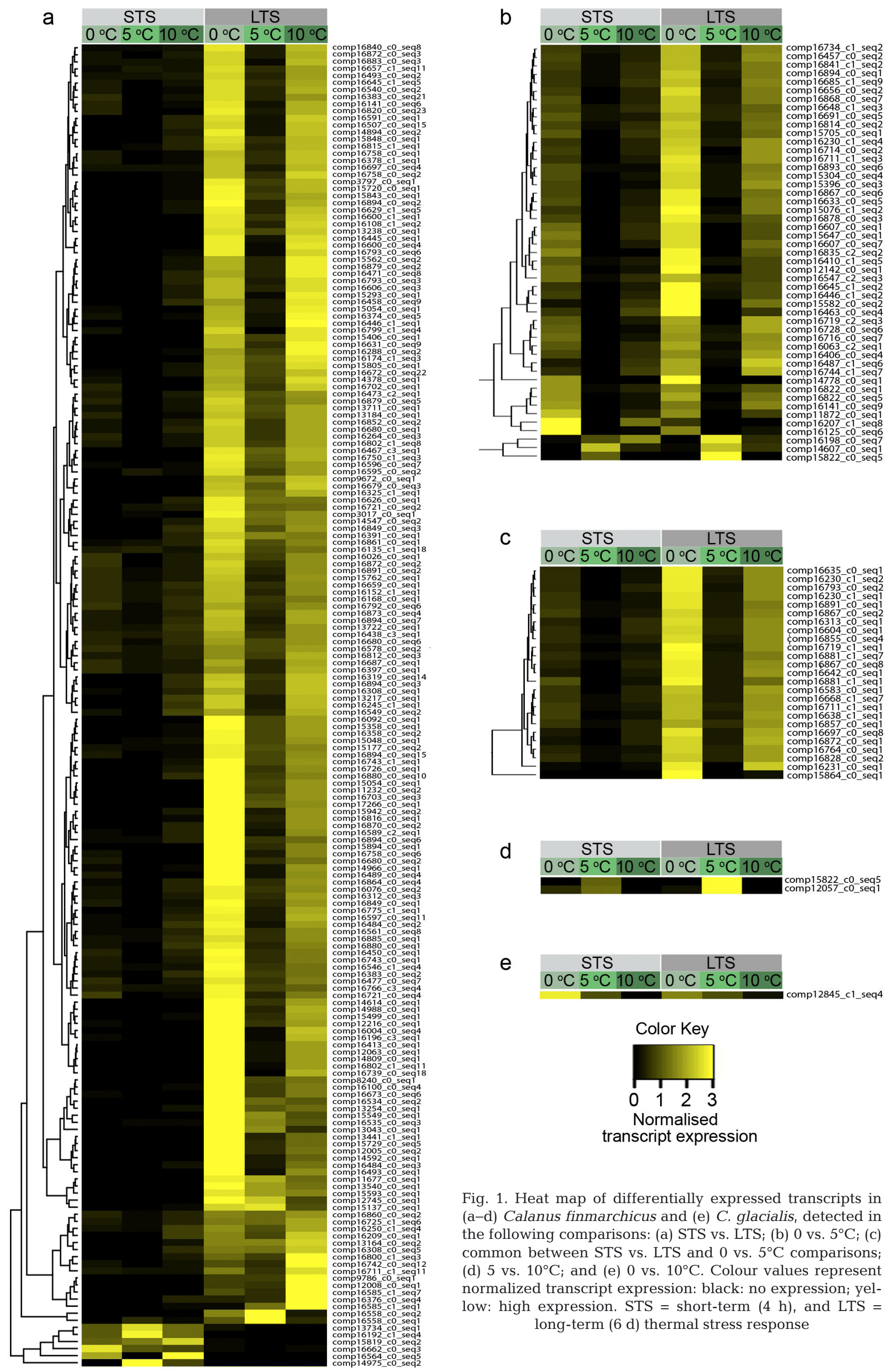

Fig. 1. Heat map of differentially expressed transcripts in (a-d) Calanus finmarchicus and (e) C. glacialis, detected in the following comparisons: (a) STS vs. LTS; (b) 0 vs. $5^{\circ} \mathrm{C}_{i}$ (c) common between STS vs. LTS and 0 vs. $5^{\circ} \mathrm{C}$ comparisons; (d) 5 vs. $10^{\circ} \mathrm{C}$; and (e) 0 vs. $10^{\circ} \mathrm{C}$. Colour values represent normalized transcript expression: black: no expression; yellow: high expression. STS = short-term $(4 \mathrm{~h})$, and LTS = long-term $(6 \mathrm{~d})$ thermal stress response 
(Table 1, Tables S3 \& S4 in Supplement 2 at www.intres.com/articles/suppl/m534p079_supp.xls). Functional classifications of annotated transcripts in $C$. finmarchicus and C. glacialis represented similar fractions of transcripts in GO categories for biological processes (Fig. S4 in Supplement 1 at www.int-res. com/articles/suppl/m534p079_supp.pdf).

\section{Differential expression}

Whole transcriptome profiling

Differential expression analysis was performed on uniquely mapped reads from each library (Fig. S3 in Supplement 1). Filtering of Trinity transcripts with baseMean < 5 counts (to minimize the influence of sequencing errors) reduced the number of transcripts to 5566 for C. finmarchicus and 8083 for C. glacialis. The range of $\log _{2} \mathrm{FC}$ in response to treatments was different for the 2 species: wider for $C$. finmarchicus

Table 1. Summary statistics and annotation success for the de novo assemblies of Calanus finmarchicus and C. glacialis transcriptomes. GC: guanine and cytosine

\begin{tabular}{|lrr|}
\hline Statistic & C. finmarchicus & C. glacialis \\
\hline Total number of cleaned reads & 4406567 & 2962408 \\
Total Trinity transcripts & 28954 & 36880 \\
Minimum transcript length (bp) & 201 & 201 \\
Mean transcript length (bp) & 353 & 427 \\
Maximum transcript length (bp) & 2945 & 4021 \\
Transcript N50 length (bp) & 354 & 471 \\
Total number of assembled bases & 10223122 & 15748460 \\
GC content for assembly (\%) & 47 & 49 \\
Total number of annotated transcripts & 13057 & 18387 \\
Annotation success (\%) & 45 & 50 \\
\hline
\end{tabular}

$\left(10.08 \pm 1.15 \log _{2}\right.$ FC) and narrower for C. glacialis $\left(7.30 \pm 0.23 \log _{2}\right.$ FC). Comparison between STS and LTS experiments revealed 212 differently expressed transcripts in C. finmarchicus but none in C. glacialis (Fig. 1). In C. finmarchicus, among these 212 transcripts, 206 were up-regulated in LTS with a mean $\log _{2}$ FC of 3.42, and 6 transcripts were down-regulated with a mean $\log _{2}$ FC of -4.2 (Table S5 in Supplement 2). Enrichment analysis of genes responsive to stress duration indicated 5 over-represented and 1 under-represented GO terms that included genes involved in molecular chaperone and protein folding activity, protein biosynthesis, DNA replication and metabolic processes (Table 2).

In C. glacialis, differential analysis of gene expression at different temperatures revealed that comparisons 0 vs. $5^{\circ} \mathrm{C}$ and 0 vs. $10^{\circ} \mathrm{C}$ had no significant differences in expressed transcripts, while one transcript (rpl14) was differentially expressed in the 0 vs. $10^{\circ} \mathrm{C}$ comparison (Table S6 in Supplement 2, Fig. 1). For C. finmarchicus, 74 and 2 differentially expressed transcripts were detected in the 0 vs. $5^{\circ} \mathrm{C}$ and 5 vs. $10^{\circ} \mathrm{C}$ comparisons, respectively, and none in the 0 vs. $10^{\circ} \mathrm{C}$ comparison (Fig. 1, Tables S7 \& S8 in Supplement 2). In the 5 vs. $10^{\circ} \mathrm{C}$ comparison, both transcripts were down-regulated at $10^{\circ} \mathrm{C}$. Of 74 differently expressed transcripts in the $0 \mathrm{vs.}$ $5^{\circ} \mathrm{C}$ comparison, 71 were down-regulated at $5^{\circ} \mathrm{C}$ with a mean $\log _{2} \mathrm{FC}$ of -3.3 . These down-regulated transcripts included molecular chaperones and heat shock proteins, proteins involved in reactive oxygen species (ROS) detoxication, proteolysis and energy metabolism (Table S7 in Supplement 2). In addition, up-regulated transcripts were functionally enriched in structural con-

Table 2. Enriched gene ontology (GO) terms among differently expressed transcripts in Calanus finmarchicus. P: biological process; F: molecular function; C: cellular component; MCM: mini-chromosome maintenance

\begin{tabular}{|c|c|c|c|c|}
\hline $\mathrm{GO}$ & Category: term & $\begin{array}{l}\text { Significant } \\
\text { genes }\end{array}$ & $\begin{array}{l}\text { Expected } \\
\text { genes }\end{array}$ & $\begin{array}{c}\text { Corrected } \\
\text { p-value }\end{array}$ \\
\hline \multicolumn{5}{|l|}{ STS vs. LTS } \\
\hline GO:0006457 & P: protein folding & 16 & 6.84 & 0.02 \\
\hline GO:0003746 & F: translation elongation factor activity & 8 & 1.12 & 0.002 \\
\hline GO:0005524 & F: ATP binding & 47 & 43.46 & 0.005 \\
\hline GO:0031681 & F: G-protein beta-subunit binding & 4 & 0.24 & 0.03 \\
\hline GO:0005737 & C: cytoplasm & 116 & 140.59 & $6.12 \times 10^{-7}$ \\
\hline GO:0042555 & C: MCM complex & 8 & 1.79 & 0.04 \\
\hline \multicolumn{5}{|l|}{0 vs. $5^{\circ} \mathrm{C}$} \\
\hline GO:0003735 & F: structural constituent of ribosome & 9 & 2.52 & 0.03 \\
\hline GO:0022627 & C: cytosolic small ribosomal subunit & 5 & 0.41 & 0.02 \\
\hline
\end{tabular}




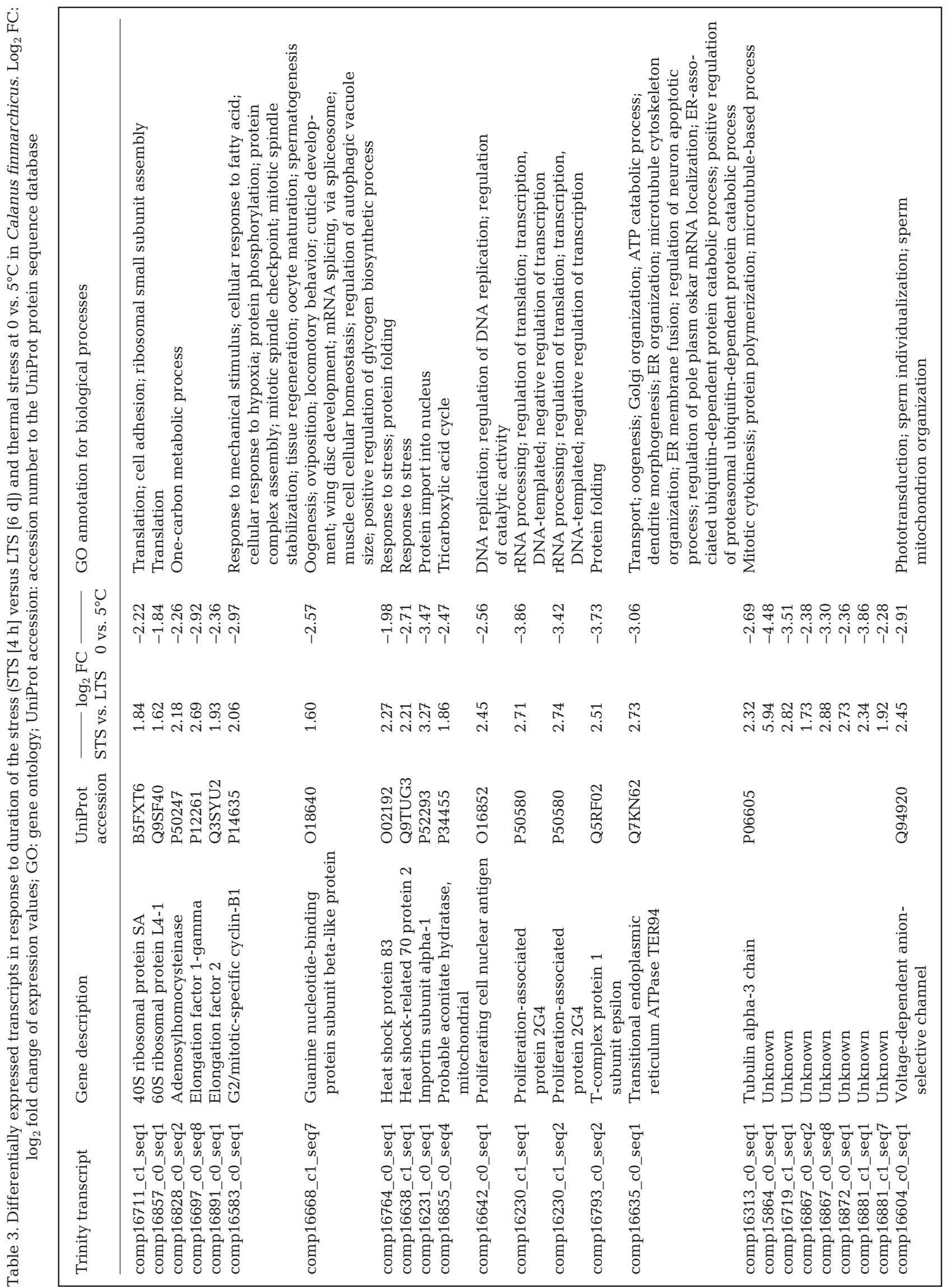



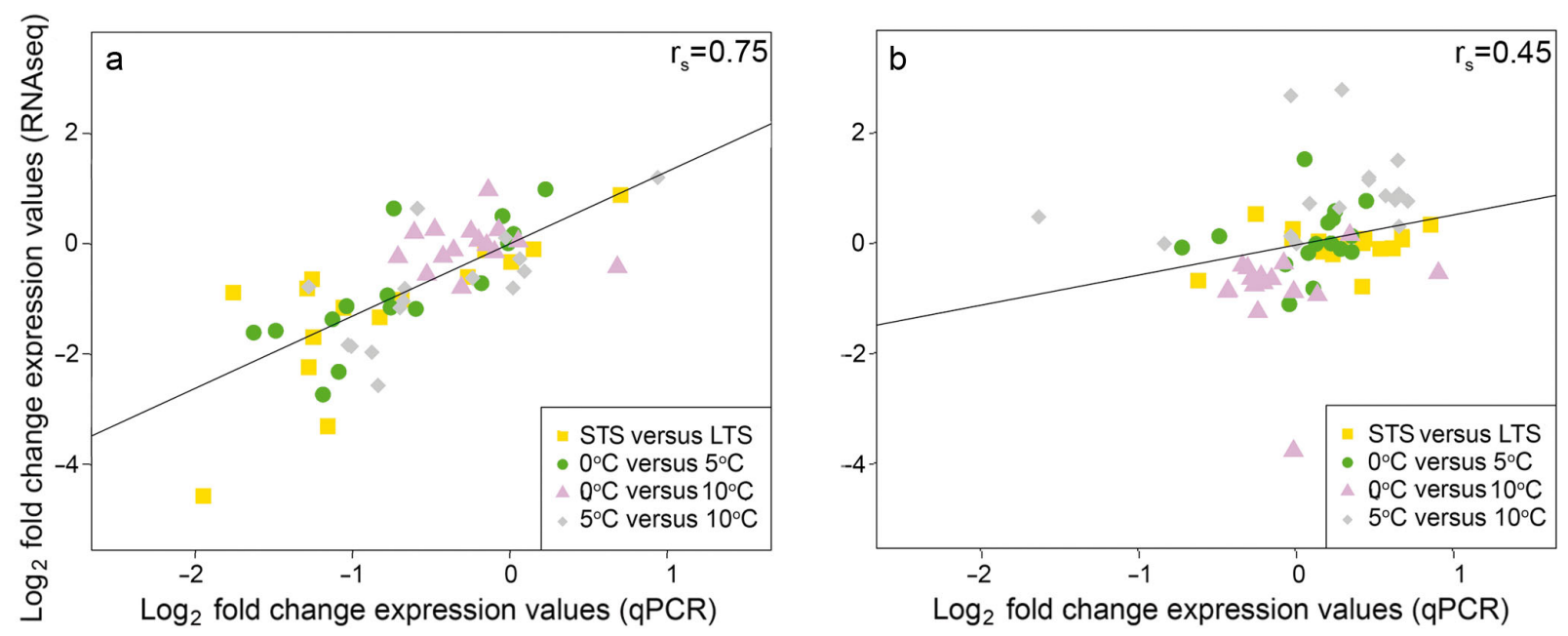

Fig. 2. Correlation between $\log _{2}$ FC expression values in all comparisons obtained with RNA-seq and qPCR for (a) Calanus finmarchicus and (b) C. glacialis

stituents of ribosome and cytosolic small ribosomal subunit (various $40 \mathrm{~S}$ and $60 \mathrm{~S}$ ribosomal proteins) (Table 2). In both STS vs. LTS and 0 vs. $5^{\circ} \mathrm{C}$ comparisons, 25 transcripts were detected (Table 3). The majority of the transcripts were related to protein biosynthesis (elongation factors and ribosomal proteins) and protein folding (HSPs and other chaperones). Others were involved in metabolic processes, transport, oogenesis, cell cycle and replication (Table 3).

\section{qPCR profiling of selected genes}

Expression values obtained by RNA-seq and qPCR were significantly correlated in C. finmarchicus $\left(\mathrm{r}_{\mathrm{S}}=\right.$ $0.75, \mathrm{p}<0.001)$ and C. glacialis $\left(\mathrm{r}_{\mathrm{S}}=0.45, \mathrm{p}<0.001\right)$ (Fig. 2). The correlation improved for C. glacialis $\left(\mathrm{r}_{\mathrm{S}}=\right.$ $0.51, \mathrm{p}<0.001)$ after filtering out 2 genes that had correlation coefficients below average: rpl14 and znf207 (Fig. S5 in Supplement 1 at www.int-res.com/ articles/suppl/m534p079_supp.pdf). FC values obtained by RNA-seq and qPCR matched for most genes and $\log _{2}$ FC values ranged from -2 to 2 (Fig. S5 in Supplement 1). Out of 5 potential reference genes, cdc42 and eif1ax were the 2 most stable in C. finmarchicus and C. glacialis under elevated temperatures (Fig. S6 in Supplement 1), and were therefore used.

In C. finmarchicus, all 11 genes of interest were significantly up-regulated in LTS compared to STS at 0,10 and/or $15^{\circ} \mathrm{C}$ (Figs. $3 \&$ 4). In C. glacialis, only 5 of 11 genes (hsp60, hsp70_3, hsp70_5, gdh and nap111) had significant differential expression (down-regulation) in LTS compared to STS at 0 and/or $10^{\circ} \mathrm{C}$ (Figs. $3 \& 4$ ). For both species, none of the selected genes were differentially expressed during STS at any temperature. During LTS in C. finmarchicus, 5 genes (dnaja1, gdh, nap111, znf207 and rps11) were significantly down-regulated at $5^{\circ} \mathrm{C}$ compared to 0 and/or $15^{\circ} \mathrm{C}$. During LTS, C. glacialis down-regulated 4 genes (dnaja1, hsp60, hsp70_3 and gdh) at $10^{\circ} \mathrm{C}$ compared to 5 and $15^{\circ} \mathrm{C}$, but showed no differential expression compared to $0^{\circ} \mathrm{C}$ (Figs. $3 \& 4$ ).

\section{DISCUSSION}

\section{Contrasting response to thermal stress}

Thermal stress responses between the temperate Calanus finmarchicus and the Arctic C. glacialis differed substantially. While over 200 transcripts were differentially expressed in response to temperature and duration of stress in C. finmarchicus, C. glacialis showed no changes in gene expression based on RNA-seq, and only a few genes displayed differential expression using $\mathrm{qPCR}$. The difference in transcriptome responses to thermal stress between the 2 Calanus spp. exceeds differences in global gene expression between sister species of mussels Mytlius galloprovincialis and M. trossulus, where the majority of genes have highly similar changes in expression (Lockwood et al. 2010).

Furthermore, closely related species pairs inhabiting cold and warm habitats often express hsps differentially. Typically, the species from a cold habitat activates overexpression of hsps at lower temperatures than the species from a warmer habitat, as shown in the congener amphipods Eulimnogamma- 

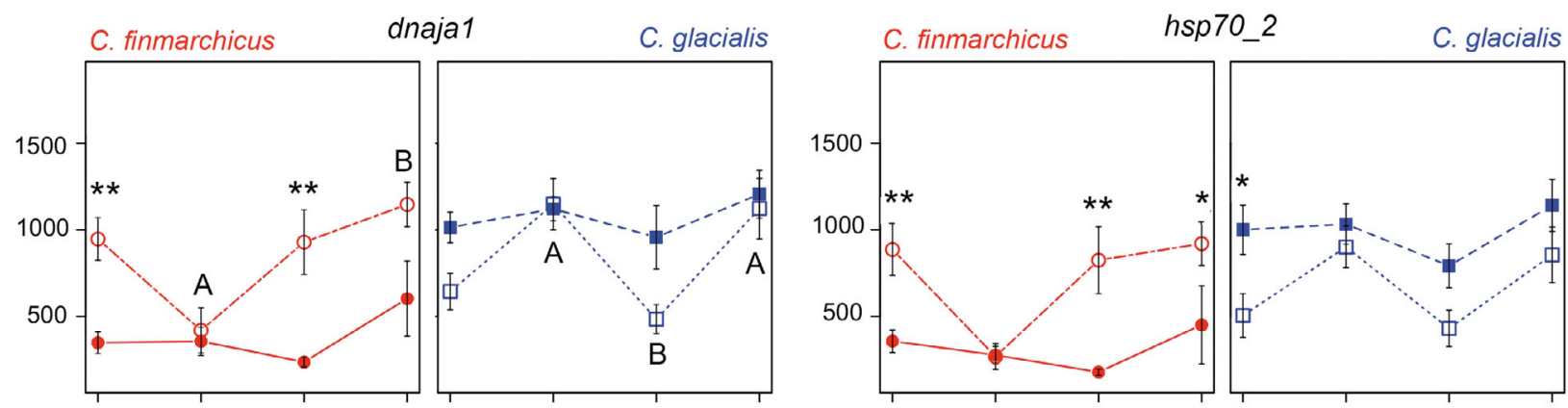

hsp10
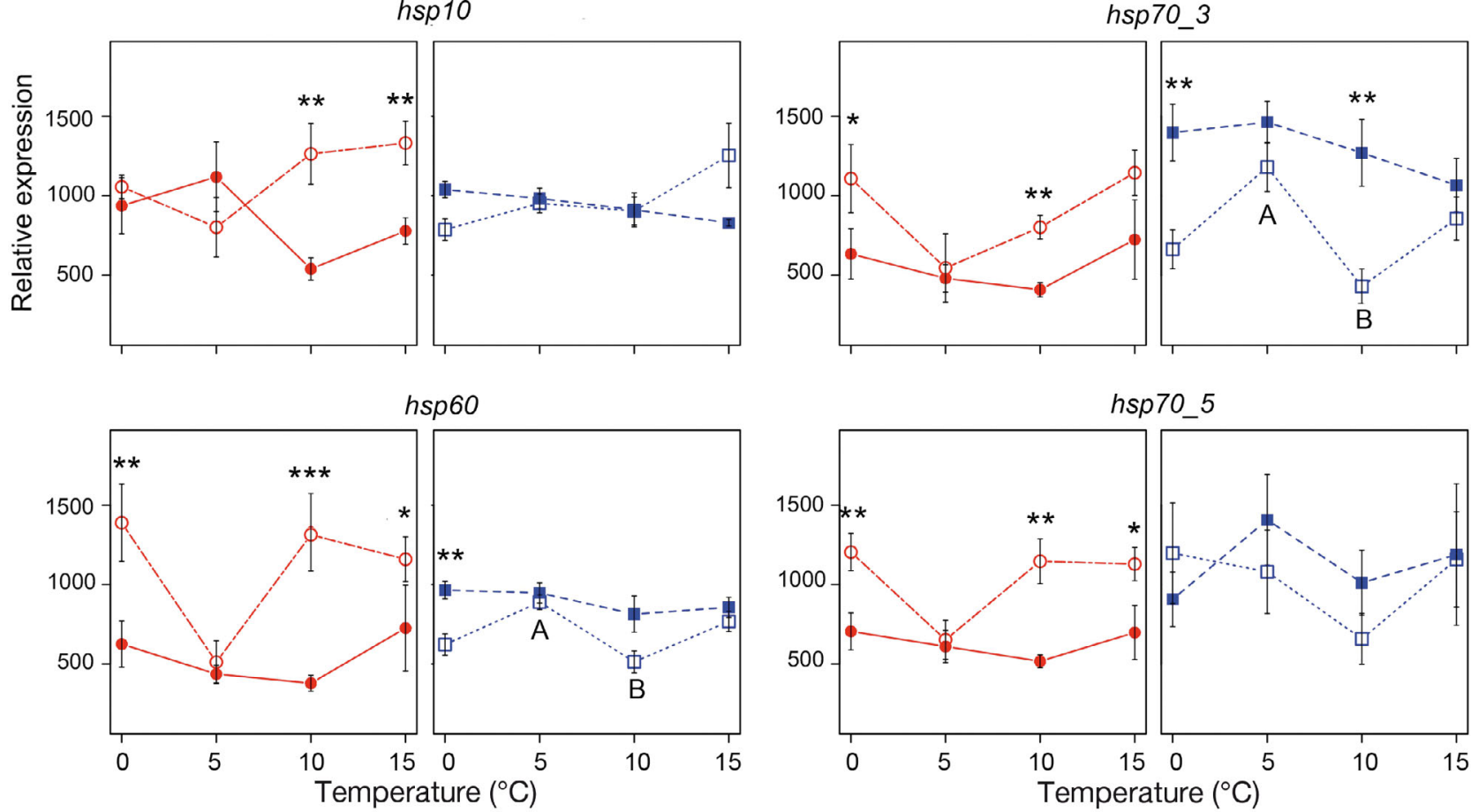

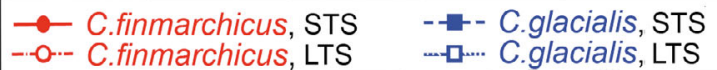

Fig. 3. Relative transcript levels of heat shock protein genes for Calanus finmarchicus and C. glacialis obtained with qPCR. STS $=$ short-term $(4 \mathrm{~h})$ and LTS $=$ long-term $(6 \mathrm{~d})$ thermal stress response. Expression values are shown as mean \pm SE. ${ }^{*} p<0.05$, ${ }^{* *} p<0.01,{ }^{* * *} p<0.001$. Different letters indicate significantly different expression values between temperatures during LTS

rus: the cold-water E. verrucosus shows a lower basal level of HSP70 and a stronger induction after thermal stress compared to E. cyaneus from warmer waters (Bedulina et al. 2013). In the present study, however, the cold-water C. glacialis showed no up-regulation of hsps and no significant changes in global gene expression with increasing temperature, whereas the temperate $C$. finmarchicus up-regulated dnaja1 (hsp40) and changed expression of 74 genes. The lack of thermal stress response in C. glacialis compared to $C$. finmarchicus is similar to divergent responses in the Antarctic ciliates Euplotes: in contrast to psychrotrophic (cold-tolerant) E. nobilii, psychrophilic (cold-loving) E. focardii lacks HSP70 up- regulation in response to thermal stress (La Terza et al. 2001).

Genes that were monitored with qPCR did not change their expression in $C$. finmarchicus or $C$. glacialis in response to increased temperatures after STS $(4 \mathrm{~h})$, but were differentially expressed in response to LTS (6 d). In addition, RNA-seq showed upregulation of over 200 transcripts in LTS compared to STS in C. finmarchicus, supporting the contention that LTS generally requires a significant change of expression for many genes to ensure cellular homeostasis (e.g. Meistertzheim et al. 2007), while $C$. glacialis did not reveal to keep homeostasis. Similarly to $C$. finmarchicus, a higher number and little 

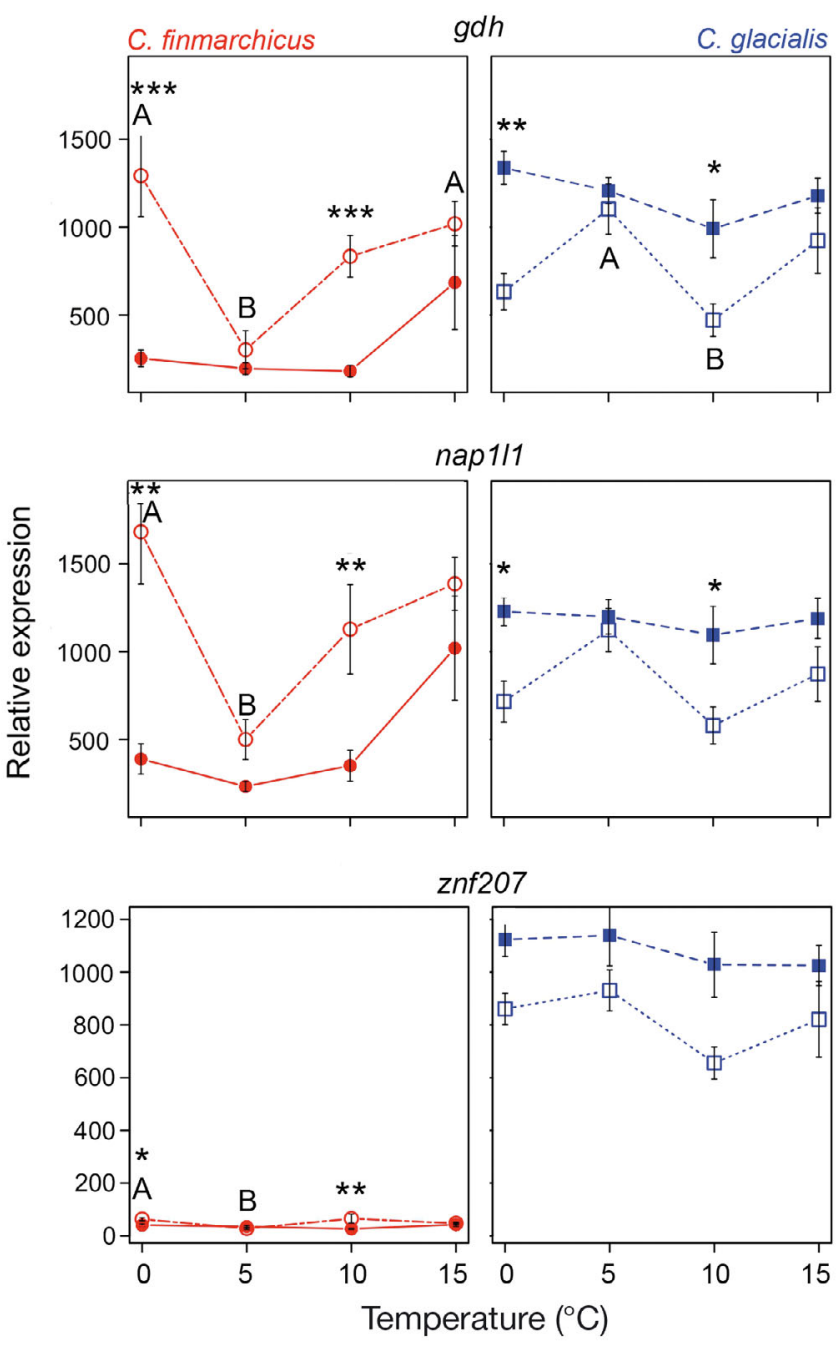

overlap between differentially expressed genes after LTS compared to STS is observed in the coral Acropora millepora under exposure to elevated temperatures (Meyer et al. 2011). Consequently, functional divergence in response to STS and LTS may exist, and highlights the importance of stress duration for experiments that aim to investigate resiliencepotential of species under climate change.

\section{Lack of thermal stress response in C. glacialis}

The absence of strong induction of stress-responsive genes in C. glacialis suggests a lack of thermal stress response. Two hypotheses explaining the absence are (1) C. glacialis was not stressed during the experiments and is more resilient than $C$. finmarchicus; and (2) C. glacialis was thermally stressed but, as a cold-water Arctic species, it may lack the

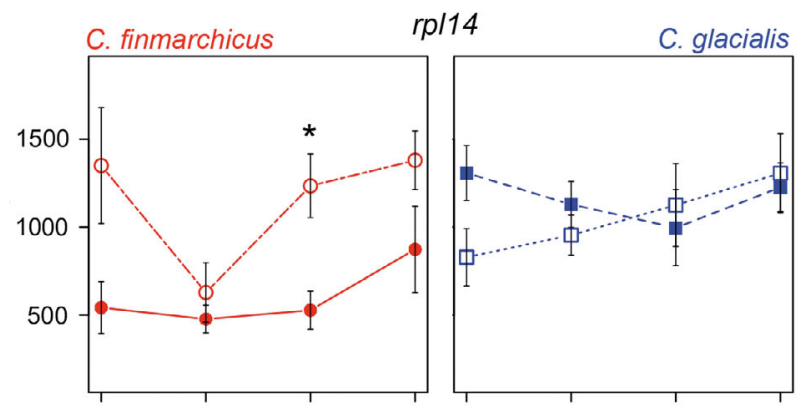

rps11

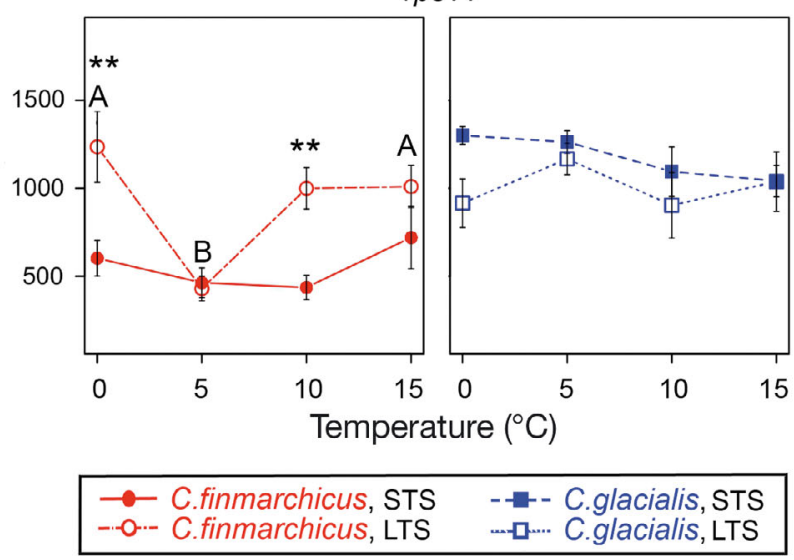

Fig. 4. Relative transcript levels of genes of interest for Calanus finmarchicus and C. glacialis obtained with qPCR. gdh: glutamate dehydrogenase; nap111: nucleosome assembly protein 1-like 1; rpl14: $60 \mathrm{~S}$ ribosomal protein L14; rps11: 40S ribosomal protein S11; znf207: zinc finger protein 207. Expression values are shown as mean $\pm \mathrm{SE} .{ }^{*} \mathrm{p}<0.05,{ }^{* *} \mathrm{p}<$ $0.01,{ }^{* * *} \mathrm{p}<0.001$. Different letters indicate significantly different expression values between temperatures during LTS

molecular mechanisms to respond to thermal stress. The second hypothesis is more likely, given that presence and abundance of $C$. glacialis in the natural environment is strongly linked to temperatures $<7^{\circ} \mathrm{C}$ (Carstensen et al. 2012), while the copepods become torpid and motionless $>15^{\circ} \mathrm{C}$ (Hirche 1987). Accordingly, physiological data from the present experiment showed decreased grazing and elevated mortality at $15^{\circ} \mathrm{C}$, supporting earlier studies at the same location showing C. glacialis sensitivity to temperatures $>7^{\circ} \mathrm{C}$ (Hjorth \& Nielsen 2011, Kjellerup et al. 2012).

A similar lack of or low-magnitude response to thermal stress was observed in several Antarctic cold-specialized species, ranging from nototheniid fishes (e.g. Trematomus bernacchii) (Buckley \& Somero 2009) to invertebrates (La Terza et al. 2001, Clark et al. 2008). In most cases only heat shock response, particularly expression of HSP70, was in- 
vestigated and absence of HSP up-regulation was detected. However, recent full transcriptome profiling in the nototheniid fish Pagothenia borchgrevinki showed that the stress response even to a small temperature increase includes a low-magnitude down-regulation of many genes including hsps (Bilyk \& Cheng 2014). Similar down-regulation of several genes (dnaja1, hsp60, hsp70_3 and gdh) at 10 compared to $5^{\circ} \mathrm{C}$ after LTS was detected in $C$. glacialis using qPCR. The lack of cellular stress response in Antarctic species is due to adaptation and specialization to stably cold Antarctic waters (Clark et al. 2008, Bilyk \& Cheng 2014). Although environmental conditions in the Arctic Ocean are more variable then in the Antarctic (Clarke \& Peck 1991), and the lack of cellular stress response has not been reported in Arctic species, the lack of thermal stress response in C. glacialis may be explained by cold-water specialization. More studies and locations are needed to confirm this hypothesis and to further explore cold-water specialization of Calanus spp. by examining another Arctic species C. hyperboreus and the Antarctic species pair C. propinquus and C. simillimus.

\section{Transcriptome-wide response to thermal stress in C. finmarchicus}

Overall, transcriptome-wide changes in C. finmarchicus involved macromolecular stabilization and repair, protein biosynthesis and proteolysis, and energy metabolism, mirroring the classical cellular stress response aiming to increase tolerance and survival of an organism (Kültz 2005). Such a response has previously been detected in various species exposed to stress, such as mussels (Lockwood et al. 2010) and copepods (Schoville et al. 2012), and includes up- and down-regulation of many genes. Although sub-lethal stress at $18^{\circ} \mathrm{C}$ for $48 \mathrm{~h}$ induces up-regulation of $h s p 70$ in C. finmarchicus (Voznesensky et al. 2004), the change of temperature from 0 to $5^{\circ} \mathrm{C}$ during LTS in the present study resulted in down-regulation of several hsps and other stressresponsive genes. The 3 hsp 70 genes that were used in qPCR in our study are distinct from those previously examined in C. finmarchicus (Voznesensky et al. 2004, Aruda et al. 2011), suggesting an even larger complexity of multiple homologues within hsp families in Calanus spp. and their differential regulation under various stresses. The genes of dnaja1, gdh and rps11 were up-regulated at 15 compared to $5^{\circ} \mathrm{C}$. Glutamate dehydrogenase ( $g d h)$, a mitochondrial en- zyme that plays a key role in the metabolism of free amino acids, responds to acute salinity stress in the Chinese mitten crab (Wang et al. 2012) but not in the euryhaline copepod T. californicus (Willett \& Burton 2003), and may have an important role in the thermal stress response in C. finmarchicus. The down-regulation of ribosomal protein genes, particularly rpl14, has been found in the copepod T. californicus in response to heat stress (Schoville et al. 2012), while large-scale up-regulation of ribosomal proteins in response to heat shock or chronic stress has been found in the Pacific oyster (Meistertzheim et al. 2007), suggesting an effort to increase translation capacity or protect ribosomal function through the addition or replacement of ribosomal proteins (Kültz 2005).

The last group of stress-responsive genes that our study targeted is involved in the cell cycle: nucleosome assembly protein 111 (nap111), which is involved in modulation of chromatin formation and regulation of cell proliferation; and zinc finger protein 207 (znf207), which can regulate chromosome alignment (Toledo et al. 2014). These genes were down-regulated at 5 compared to $0^{\circ} \mathrm{C}$ and upregulated under LTS, and may be important for cell cycle regulation under stressful conditions. An overexpression of nap111 was found in response to hyperosmotic stress in European whitefish (Papakostas et al. 2012), while there is no reported evidence about the involvement of znf207 in stress response. Additionally, RNA-seq analysis in C. finmarchicus revealed more differentially expressed genes connected to cell cycle, meiosis and oogenesis.

The large-scale down-regulation of genes at 5 compared to 0 (RNA-seq) and $15^{\circ} \mathrm{C}$ (several genes targeted with qPCR including several hsps), together with the fact that many of hsps are stress-inducible genes (Feder \& Hofmann 1999), suggests $5^{\circ} \mathrm{C}$ to be the more optimal temperature for $C$. finmarchicus from Disko Bay. This is supported by physiological experiments on $C$. finmarchicus from the same area during the spring bloom showing an increase in grazing and egg production from 0.5 to $10^{\circ} \mathrm{C}$ (Hjorth \& Nielsen 2011, Kjellerup et al. 2012) and the fact that C. finmarchicus has an annual temperature optimum of approximately $5^{\circ} \mathrm{C}$ (Wilson et al. 2015). Nevertheless, in the Norwegian Sea, $10^{\circ} \mathrm{C}$ is regarded as optimal for C. finmarchicus (Harris et al. 2000), while populations from the North Sea show the highest population growth rate at $12^{\circ} \mathrm{C}$ (Møller et al. 2012). Thus, physiological and gene expression plasticity of C. finmarchicus may be of particular importance for mitigating climate change, as $C$. finmarchicus might cross the limit of its thermal niche for several months 
per year in the North Sea (Helaouët et al. 2011) by 2100. Even if examples of locally adapted populations with different thermotolerance are known for copepods, such as Tigriopus californicus (Schoville et al. 2012), more detailed studies are needed to investigate a contribution of both genetic adaptation and phenotypic plasticity into the thermal tolerance of $C$. finmarchicus.

\section{Reliability of approach}

The overall good agreement between RNA-seq and qPCR (Fig. 1, Fig. S5 in Supplement 1 at www. int-res.com/articles/suppl/m534p079_supp.pdf) demonstrates the reliability of our RNA-seq results, particularly in C. finmarchicus, where the correlation is similar to other studies on non-model species (e.g. Meyer et al. 2011). The reduced strength of correlation between qPCR and RNA-seq in C. glacialis is likely due to the limited sequencing depth and small $\mathrm{FC}$ in gene expression under stress conditions. Despite the close match of $\log _{2}$ FC of qPCR and RNAseq, statistical analysis of qPCR data resulted in better resolution of differently expressed genes, indicating weaker discriminative power of RNA-seq analysis, which could originate from pooling replicates into one library per treatment. We followed Biswas et al. (in press) as most differentially expressed genes can be called with a biologically averaged (pooled) design. Nonetheless, replicates of pools may add power to the statistical test to identify subtle changes in gene expression (Kendziorski et al. 2005) observed in C. glacialis.

In the experiments, we tried to minimize the influence of factors other than temperature. Nevertheless, maturation of gonads and oocytes in used females, as well as egg production, may result in some of the observed changes during LTS, particularly those connected to cell cycle, meiosis and oogenesis. In addition, phytoplankton grazed by Calanus spp. could be utilized for growth, maturation of gonads and egg production (Falk-Petersen et al. 2007), and thus may influence gene expression. The diatom Thalassiosira weissflogii diet is widely used in longterm experiments with live Calanus spp. (e.g. Hjorth \& Nielsen 2011, Kjellerup et al. 2012) without apparent detrimental effects on physiology. Nonetheless, this diatom diet has been shown to affect egg production and hatching success in the long term (14 d) in another copepod species (Temora stylifera, Ceballos \& Ianora 2003), and feeding of C. helgolandicus on toxic diatom Skeletonema marinoi resulted in up- regulation of genes involved in protein folding or degradation, and re-organization of actin and tubulin filaments (Carotenuto et al. 2014).

\section{Conclusion and future perspectives}

The low-magnitude transcriptional response in $C$. glacialis to thermal stress suggests that this species has limited potential to respond to novel thermal conditions via a change in gene expression. Integration of these results with laboratory and field observations suggests that, under climate change, C. glacialis might be a vulnerable element in the Arctic ecosystem. New regulatory mechanisms involved in stress response, however, have been recently highlighted (e.g. microRNAs, long non-coding RNAs and epigenetics). Consequently, it may be possible for species (e.g. C. glacialis) that do not show a strong transcriptomic response to thermal stress to have alternative mechanisms to cope with temperature changes. Additionally, knowledge about population genetic structure of the 2 species in space and time, as well as the role of thermal history in thermal tolerance of the species, will lead to a better understanding of their resilience potential to climate change.

Acknowledgements. We thank Anna Abramova for assistance with the RNA/DNA extraction, Alexander Jüterbock for his help with the bioinformatics, James Coyer for his comments on the manuscript, Vittoria Roncalli for productive discussions and Petra Lenz for hosting I.S. in her team and for her comments on the manuscript. We thank the 3 anonymous reviewers for constructive comments for improvements of the original manuscript. The study was funded by European Commission FP7 EURO-BASIN (Grant Agreement 264 933) and the Norwegian Research Council (projects HAVKYST 216578 and Forsksam 234356).

Data accessibility. Sequence data and the de novo assemblies have been submitted to the National Center of Biotechnology Information (www.ncbi.nlm.nih.gov) under bioproject numbers PRJNA236983 (C. finmarchicus) and PRJNA 237014 (C. glacialis).

\section{LITERATURE CITED}

Alexa A, Rahnenfuhrer J (2010) topGO: enrichment analysis for gene ontology. R package version 2.16.0, www. bioconductor.org/packages/release/bioc/html/topGO.html

Aruda AM, Baumgartner MF, Reitzel AM, Tarrant AM (2011) Heat shock protein expression during stress and diapause in the marine copepod Calanus finmarchicus. J Insect Physiol 57:665-675

Barshis DJ, Ladner JT, Oliver TA, Palumbi SR (2014) Lineage-specific transcriptional profiles of Symbiodinium spp. unaltered by heat stress in a coral host. Mol Biol 
Evol 31:1343-1352

Beaugrand G, Reid F, Ibañez F, Lindley JA and others (2002) Reorganization of North Atlantic marine copepod biodiversity and climate. Science 296:1692-1694

Beaugrand G, Luczak C, Edwards M (2009) Rapid biogeographical plankton shifts in the North Atlantic Ocean. Glob Change Biol 15:1790-1803

- Bedulina DS, Evgen'ev MB, Timofeyev MA, Protopopova MV and others (2013) Expression patterns and organization of the $h s p 70$ genes correlate with thermotolerance in two congener endemic amphipod species (Eulimnogammarus cyaneus and E. verrucosus) from Lake Baikal. Mol Ecol 22:1416-1430

Benjamini Y, Hochberg Y (1995) Controlling the false discovery rate: a practical and powerful approach to multiple testing. J R Stat Soc B Methodol 57:289-300

Bilyk KT, Cheng CC (2014) RNA-seq analyses of cellular responses to elevated body temperature in the high Antarctic cryopelagic nototheniid fish Pagothenia borchgrevinki. Mar Genomics 18:163-171

Biswas S, Agrawal YN, Mucyn TS, Dangl JL and others (in press) Biological averaging in RNA-seq. http://arxiv.org/ abs/1309.0670

Blachowiak-Samolyk K, Søreide JE, Kwasniewski S, Sundfjord A and others (2008) Hydrodynamic control of mesozooplankton abundance and biomass in northern Svalbard waters (79-81 degrees N). Deep-Sea Res II 55: 2210-2224

Bonnet D, Richardson A, Harris R, Hirst A (2005) An overview of Calanus helgolandicus ecology in European waters. Prog Oceanogr 65:1-53

Buckley BA, Somero GN (2009) cDNA microarray analysis reveals the capacity of the cold-adapted Antarctic fish Trematomus bernacchii to alter gene expression in response to heat stress. Polar Biol 32:403-415

> Bucklin A, Frost BW, Kocher D (1995) Molecular systematics of six Calanus and three Metridia species (Calanoida: Copepoda). Mar Biol 121:655-664

Carotenuto Y, Dattolo E, Lauritano C, Pisano F and others (2014) Insights into the transcriptome of the copepod Calanus helgolandicus feeding on the oxylipin-producing diatom Skeletonema marinoi. Harmful Algae 31: 153-162

Carstensen J, Weidmann A, Olszewska A, Kwasniewski S (2012) Effects of environmental conditions on the biomass of Calanus spp. in the Nordic seas. J Plankton Res 34:951-966

> Ceballos S, Ianora A (2003) Different diatoms induce contrasting effects in the copepod Temora stylifera. J Exp Mar Biol Ecol 294:189-202

> Chust G, Castellani C, Licandro P, Ibaibarriaga L and others (2014) Are Calanus spp. shifting poleward in the North Atlantic? A habitat modelling approach. ICES J Mar Sci 71:241-253

Clark MS, Fraser KPP, Peck LS (2008) Lack of an HSP70 heat shock response in two Antarctic marine invertebrates. Polar Biol 31:1059-1065

> Clarke A, Peck LS (1991) The physiology of polar marine zooplankton. Polar Res 10:355-370

> Conover RJ (1988) Comparative life histories in the genera Calanus and Neocalanus in high latitudes of the northern hemisphere. Hydrobiologia 167-168:127-142

Falk-Petersen S, Pavlov V, Timofeev S, Sargent JR (2007) Climate variability and possible effects on Arctic food chains: the role of Calanus. In: Ørbæk JB, Kallenborn R,
Tombre I, Hegseth EN, Falk-Petersen S, Hoel AH (eds) Arctic alpine ecosystems and people in a changing environment. Springer-Verlag, Berlin, p 147-166

> Falk-Petersen S, Mayzaud P, Kattner G, Sargent JR (2009) Lipids and life strategy of Arctic Calanus. Mar Biol Res 5: 18-39

> Feder ME, Hofmann GE (1999) Heat-shock proteins, molecular chaperones, and the stress response: evolutionary and ecological physiology. Annu Rev Physiol 61:243-282

> Haas BJ, Papanicolaou A, Yassour M, Grabherr M and others (2013) De novo transcript sequence reconstruction from RNA-seq using the Trinity platform for reference generation and analysis. Nat Protoc 8:1494-1512

Hansen J, Sato M, Ruedy R, Lo K and others (2006) Global temperature change. Proc Nat Acad Sci USA 103: 14288-14293

> Hansen BH, Altin D, Øverjorder IB, Jager $\mathrm{T}$ and others (2013) Acute exposure of water soluble fractions of marine diesel on Arctic Calanus glacialis and boreal Calanus finmarchicus: effects on survival and biomarker response. Sci Total Environ 449:276-284

Harrell Jr. FE (2014) Hmisc: Harrell miscellaneous. R package version 3.14-4. http://CRAN.R-project.org/ package $=$ Hmisc

> Harris RP, Irigoien X, Head RN, Hygum BH and others (2000) Feeding, growth, and reproduction in the genus Calanus. ICES J Mar Sci 57:1708-1726

> Helaouët P, Beaugrand G, Reid PC (2011) Macrophysiology of Calanus finmarchicus in the North Atlantic Ocean. Prog Oceanogr 91:217-228

> Helaouët P, Beaugrand G (2007) Macroecology of Calanus finmarchicus and C. helgolandicus in the North Atlantic Ocean and adjacent seas. Mar Ecol Prog Ser 345: 147-165

> Hildebrandt N, Niehoff B, Sartoris FJ (2014) Long-term effects of elevated $\mathrm{CO}_{2}$ and temperature on the Arctic calanoid copepods Calanus glacialis and C. hyperboreus. Mar Pollut Bull 80:59-70

Hirche HJ (1987) Temperature and plankton. II. Respiration and swimming activity of copepods from the Greenland Sea at different temperatures. Mar Biol 94:347-356

Hjorth M, Nielsen TG (2011) Oil exposure in a warmer Arctic: potential impacts on key zooplankton species. Mar Biol 158:1339-1347

> Hofmann GE, Todgham AE (2010) Living in the now: physiological mechanisms to tolerate a rapidly changing environment. Annu Rev Physiol 72:127-145

Ion RNA-Seq (2012) Methods, tools, and pipelines for analysis of Ion PGM Sequencer miRNA and gene expression data. White paper. Life Technologies Corporation, Carlsbad, CA

Kendziorski C, Irizarry RA, Chen KS, Haag JD and others (2005) On the utility of pooling biological samples in microarray experiments. Proc Nat Acad Sci USA 102: 4252-4257

> Kjellerup S, Dünweber M, Swalethorp R, Nielsen TG and others (2012) Effects of a future warmer ocean on the coexisting copepods Calanus finmarchicus and $C$. glacialis in the Disko Bay, western Greenland. Mar Ecol Prog Ser 447:87-108

Konietschke F (2012) nparcomp: perform multiple comparisons and compute simultaneous confidence intervals for the nonparametric relative contrast effects. R package version 2.0. http://CRAN.R-project.org/package= nparcomp 
Koressaar T, Remm M (2007) Enhancements and modifications of primer design program Primer3. Bioinformatics 23:1289-1291

Kültz D (2005) Molecular and evolutionary basis of the cellular stress response. Annu Rev Physiol 67:225-257

La Terza A, Papa G, Miceli C, Luporini P (2001) Divergence between two Antarctic species of the ciliate Euplotes, E. focardii and E. nobilii, in the expression of heat-shock protein 70 genes. Mol Ecol 10:1061-1067

La Terza A, Miceli C, Luporini P (2004) The gene for the heat-shock protein 70 of Euplotes focardii, an Antarctic psychrophilic ciliate. Antarct Sci 16:23-28

Langmead B, Salzberg S (2012) Fast gapped-read alignment with Bowtie 2. Nat Methods 9:357-359

> Liao Y, Smyth GK, Shi W (2013) The Subread aligner: fast, accurate and scalable read mapping by seed-and-vote. Nucleic Acids Res 41:e108

> Liao Y, Smyth GK, Shi W (2014) featureCounts: an efficient general-purpose program for assigning sequence reads to genomic features. Bioinformatics 30:923-930

> Lockwood BL, Sanders JG, Somero GN (2010) Transcriptomic responses to heat stress in invasive and native blue mussels (genus Mytilus): molecular correlates of invasive success. J Exp Biol 213:3548-3558

Love MI, Huber W, Anders S (2014) Moderated estimation of fold change and dispersion for RNA-seq data with DESeq2. Genome Biol 15:550

> Meistertzheim AL, Tanguy A, Moraga D, Thébault MT (2007) Identification of differentially expressed genes of the Pacific oyster Crassostrea gigas exposed to prolonged thermal stress. FEBS J 274:6392-6402

- Meyer E, Aglyamova GV, Matz MV (2011) Profiling gene expression responses of coral larvae (Acropora millepora) to elevated temperature and settlement inducers using a novel RNA-seq procedure. Mol Ecol 20:3599-3616

Møller EF, Maar M, Jónasdóttir SH, Nielsen TG and others (2012) The effect of changes in temperature and food on the development of Calanus finmarchicus and Calanus helgolandicus populations. Limnol Oceanogr 57:211-220

Mukaka MM (2012) Statistics corner: a guide to appropriate use of correlation coefficient in medical research. Malawi Med J 24:69-71

> Nielsen TG, Kjellerup S, Smolina I, Hoarau G and others (2014) Live discrimination of Calanus glacialis and C. finmarchicus females: can we trust phenological differences? Mar Biol 161:1299-1306

Papakostas S, Vasemägi A, Vähä JP, Himberg M and others (2012) A proteomics approach reveals divergent molecular responses to salinity in populations of European whitefish (Coregonus lavaretus). Mol Ecol 21:3516-3530

> Pasternak A, Riser CW, Arashkevich E, Rat'kova T and others (2002) Calanus spp. grazing affects egg production and vertical carbon flux (the marginal ice zone and open Barents Sea). J Mar Syst 38:147-164

Pfaffl MW, Horgan GW, Dempfle L (2002) Relative expression software tool (REST) for group-wise comparison and statistical analysis of relative expression results in realtime PCR. Nucleic Acids Res 30:e36

Provan J, Beatty G, Maggs CA, Savidge G (2007) Expressed sequence tag-derived microsatellites for the cool-water marine copepod Calanus finmarchicus. Mol Ecol Notes 7 : 1369-1371

Editorial responsibility: Edward Durbin, Narragansett, Rhode Island, USA
R Development Core Team (2011) R: a language and environment for statistical computing. R Foundation for Statistical Computing, Vienna

Schoville SD, Barreto FS, Moy GW, Wolff A and others (2012) Investigating the molecular basis of local adaptation to thermal stress: population differences in gene expression across the transcriptome of the copepod Tigriopus californicus. BMC Evol Biol 12:170

> Smith S, Bernatchez L, Beheregaray LB (2013) RNA-seq analysis reveals extensive transcriptional plasticity to temperature stress in a freshwater fish species. BMC Genomics 14:375

Smolina I, Kollias S, Poortvliet M, Nielsen TG and others (2014) Genome- and transcriptome-assisted development of nuclear insertion/deletion markers for Calanus species (Copepoda: Calanoida) identification. Mol Ecol Resour 14:1072-1079

Tarrant AM, Baumgartner MF, Verslycke T, Johnson CL (2008) Differential gene expression in diapausing and active Calanus finmarchicus (Copepoda). Mar Ecol Prog Ser 355:193-207

> Thackeray SJ, Jones ID, Maberly SC (2008) Long-term change in the phenology of spring phytoplankton: species-specific responses to nutrient enrichment and climatic change. J Ecol 96:523-535

Toledo CM, Herman JA, Olsen JB, Ding Y and others (2014) BuGZ is required for Bub3 stability, Bub1 kinetochore function, and chromosome alignment. Dev Cell 28: 282-294

> Vandesompele J, De Preter K, Pattyn F, Poppe B and others (2002) Accurate normalization of real-time quantitative RT-PCR data by geometric averaging of multiple internal control genes. Genome Biol 3:research0034.1-research 0034.11

> Verghese J, Abrams J, Wang Y, Morano KA (2012) Biology of the heat shock response and protein chaperones: budding yeast (Saccharomyces cerevisiae) as a model system. Microbiol Mol Biol Rev 76:115-158

Voznesensky M, Lenz PH, Spanings-Pierrot C, Towle DW (2004) Genomic approaches to detecting thermal stress in Calanus finmarchicus (Copepoda: Calanoida). J Exp Mar Biol Ecol 311:37-46

- Wang Z, Gerstein M, Snyder M (2009) RNA-seq: a revolutionary tool for transcriptomics. Nat Rev Genet 10:57-63

> Wang Y, Li E, Yu N, Wang X and others (2012) Characterization and expression of glutamate dehydrogenase in response to acute salinity stress in the Chinese mitten crab, Eriocheir sinensis. PLoS ONE 7:e37316

Warnes GR, Bolker B, Bonebakker L, Gentleman RG and others (2014) gplots: various $\mathrm{R}$ programming tools for plotting data. R package version 2.14.1. http://CRAN.Rproject.org/package $=$ gplots

> Wassmann P, Duarte C, Agusti S, Sejr MK (2011) Footprints of climate change in the Arctic marine ecosystem. Glob Change Biol 17:1235-1249

Willett CS, Burton RS (2003) Characterization of the glutamate dehydrogenase gene and its regulation in a euryhaline copepod. Comp Biochem Physiol B 135:639-646

Wilson RG, Speirs DC, Heath MR (2015) On the surprising lack of differences between two congeneric calanoid copepod species, Calanus finmarchicus and C. helgolandicus. Prog Oceanogr 134:413-431

Submitted: March 23, 2015; Accepted: June 17, 2015

Proofs received from author(s): August 17, 2015 